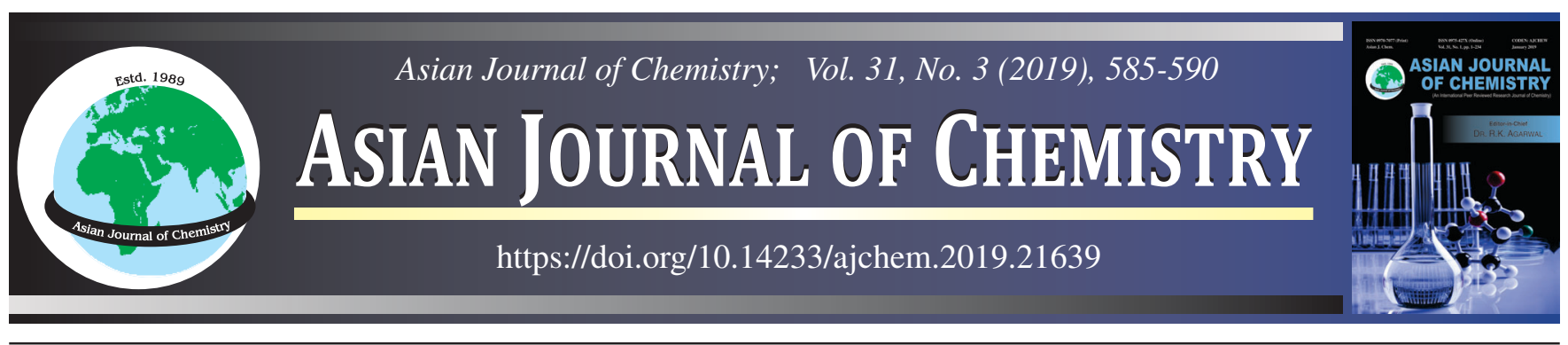

\title{
A Mixture of Iodide Ion and Gum Exudates of Eucalyptus globules as Green Inhibitor for Dissolution Control of Mild Steel in 1 N HCl Medium
}

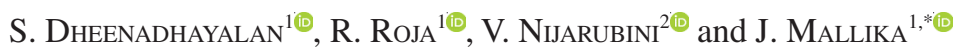

${ }^{1}$ Department of Chemistry, PSG College of Arts and Science, Coimbatore-641014, India

${ }^{2}$ Department of Chemistry, Dr. N.G.P. Arts and Science College, Coimbatore-641048, India

*Corresponding author: E-mail: jmchempsg@gmail.com

Received: 9 August 2018;

Accepted: 31 October 2018;

Published online: 31 January 2019;

AJC-19250

\begin{abstract}
The mild steel dissolution in $1 \mathrm{~N} \mathrm{HCl}$ medium was monitored in the presence and absence of gum exudates of Eucalyptus globles (GEG) using quantitative gravimetric method at 303-323 K. The synergistic influence of iodide ions with GEG on the dissolution of mild steel was also studied at 303-323 K. The impedance $\left(\mathrm{R}_{\mathrm{ct}}\right.$ and $\left.\mathrm{C}_{\mathrm{dl}}\right)$ and polarization $\left(\mathrm{b}_{\mathrm{a}}, \mathrm{b}_{\mathrm{c}}, \mathrm{i}_{\mathrm{corr}}, \mathrm{E}_{\mathrm{corr}}\right)$ parameters were obtained from electrochemical methods for the optimum concentration of GEG and GEG + $\mathrm{I}^{-}$. The dissolution of mild steel decreases with increase in the concentration of GEG and GEG $+\mathrm{I}^{-}$at $30^{\circ} \mathrm{C}$. But their inhibition ability of tested inhibitor system for dissolution control of mild steel decreases with increase in temperature but rate of dissolution of mild steel is comparatively less in the case of GEG $+\mathrm{I}^{-}$. Adsorption of GEG on mild steel obeys Langmuir's isotherm and supports physisorption process. Tafel's parameters confirm the mixed nature of the studied inhibitor.
\end{abstract}

Key

Keywords: Eucalyptus globles, Mild steel, Synergism, Physisorption, Langmuir isotherm.

\section{INTRODUCTION}

Carbohydrates obtained from plant and animal sources are biopolymers existing as products of biochemical processes of living system due to its non-toxic and eco friendly nature. Several investigators reported that the carboxymethyl and hydroxyethyl cellulose, starch, pectin and pectates, substituted/ modified chitosans, carrageenan, dextrin/cyclodextrins, alginates as green carbohydrate biopolymers for corrosion inhibition of various metal and their alloys in both acidic or alkaline or neutral environments [1]. This is because they are molecules with long chain carbon linkage having multiple adsorption sites and thus block large surface area of the corroding metal, thereby blanketing the surface and protecting the metal from aggressive environment. Gums obtained from the plant sources (carbohydrate biopolymer) have been used for centuries in a variety of fields such as food industries, pharmaceutical, cosmetics, textiles and lithography. Recently these gum exudates have been found to be good agents against metal dissolution due to presence of enormous functional groups and their ability to form complex with metal ions at surface and also its unique inhibiting strength with macromolecules, biodegradability and eco friendly nature [2]. As a contribution to the current interest on environmental friendly, green, corrosion inhibitors, the present study investigates the gum exudates from Eucalyptus globles (GEG) as non-toxic green adhesive as well as inhibitor for dissolution control of mild steel in $1 \mathrm{~N} \mathrm{HCl} \mathrm{using} \mathrm{the} \mathrm{gravi-}$ metric, Tafel's polarization and impedance measurements. The adhesive nature or binding capacity of GEG on mild steel in $1 \mathrm{~N} \mathrm{HCl}$ is found to be less significant at higher temperature. Therefore the adsorption strength as well as corrosion inhibition effectiveness of GEG on mild steel surface can be synergistically enhanced using iodide ions which are good ligands [3-8]. Therefore in present study the synergistic corrosion inhibition effect of iodide ion with GEG on the dissolution control of mild steel in $1 \mathrm{~N} \mathrm{HCl}$ at $303-323 \mathrm{~K}$ has also been studied.

\section{EXPERIMENTAL}

Preparation: Mild steel have the composition of 0.0460 wt. \% C, 0.28 wt. \% Mn, 0.019 wt. \% P, 0.020 wt. \% S, 0.006 wt. \% Si and rest of iron with dimensions of $2.5 \mathrm{~cm} \times 1 \mathrm{~cm} \times$

This is an open access journal, and articles are distributed under the terms of the Creative Commons Attribution-NonCommercial-ShareAlike 4.0 (CC BY-NC-SA 4.0) International License which allows readers to freely read, download, copy, distribute, print, search, or link to the full texts of its articles and to use them for any other lawful non-commercial purpose as long as the original source is duly acknowledged. 
$0.1 \mathrm{~cm}$ were used. The mild steel coupons of the above mentioned dimensions were polished using different grades of emery sheets, washed with distilled water, dried, degreased with acetone and then used for weight loss method. The GEG was collected at Nilgiri hills, Tamil Nadu, India. The gum is transparent with pale-yellow to amber or light brown colour. It may darken to brown with age. The gum dissolves freely in water, giving a light-brown viscous solution. The collected gum was made into slurry by using distilled water. It was strained through muslin cloth to remove the suspending impurities. The fine impurities were removed using quantitative filter paper. The resulting mucilage was dried in a desiccator to obtain a glassy mass. The GEG solution was prepared by using double distilled water and used for weight loss and electrochemical studies. The potassium iodide of analytical grade was used as synergistic additive. The acid solution was prepared by the dilution of the AnalaR grade concentrated $\mathrm{HCl}$ using de-ionized water and standardized.

Gravimetric studies: The well cleaned mild steel coupons were weighed and are immersed in the inhibited and uninhibited $1 \mathrm{~N} \mathrm{HCl}$ solution for $1 \mathrm{~h}$ immersion period at 303-323 $\mathrm{K}$. After immersion of $1 \mathrm{~h}$ period, the coupons were taken out, rinsed with de-ionized water and dried. The dried mild steel coupons were weighed to determine the weight loss. The average weight loss of the specimens in the presence and absence of GEG alone and GEG + $\mathrm{I}^{-}$were taken and corrosion rate, inhibition efficiency and surface coverage were calculated employing the eqns. 1-3.

$$
\text { Corrosion rate }(\mathrm{mmpy})=\frac{87.6 \times \mathrm{W}}{\rho \mathrm{At}}
$$

where, $\mathrm{W}$ is the weight loss $(\mathrm{g})$, ' $\rho$ ' the density of the mild steel specimen $\left(\mathrm{g} \mathrm{cm}^{-3}\right)$, 'A' the area of specimen $\left(\mathrm{cm}^{2}\right)$ and ' $\mathrm{t}$ ' is the time of immersion (h).

$$
\begin{gathered}
\text { Inhibition efficiency }(I E)=\frac{W_{o}-W_{i}}{W_{o}} \times 100 \\
\text { Surface coverage }(\theta)=\frac{W_{o}-W_{i}}{W_{o}}
\end{gathered}
$$

where, $\mathrm{W}_{\mathrm{o}}$ and $\mathrm{W}_{\mathrm{i}}$ are the weight losses of mild steel coupons in uninhibited and inhibited solution respectively.

Tafel's polarization studies: The three electrode cell assembly with the capacity of $100 \mathrm{~mL}$ was used for electrochemical measurement. The cell consisted of a saturated calomel electrode (SCE) as reference electrode and platinum counter electrode. The polarization studies were carried out over the potential range of +200 to $-200 \mathrm{mV}$ with respect to the open circuit potential at a scan rate of $1 \mathrm{mV} \mathrm{s}^{-1}$. The linear Tafel segments of the anodic and cathodic curves were extrapolated to corrosion potential at the point of intersection to obtain the corrosion potential ( $\left.\mathrm{E}_{\text {corr }}\right)$ and corrosion current density $\left(\mathrm{i}_{\text {corr }}\right)$. The inhibition efficiency was evaluated from the measured $\mathrm{i}_{\text {corr }}$ values using eqn. 4 :

$$
\text { Inhibition efficiency }=\frac{i_{\text {corr }}^{o}-i_{\text {corr }}}{i_{\text {corr }}^{o}} \times 100
$$

where, $\mathrm{i}_{\text {corr }}$ and $\mathrm{i}_{\text {corr }}$ is the corrosion current density without and with inhibitor respectively.

Impedance studies: The impedance tests were performed using AC signals of $10 \mathrm{mV}$ amplitude over the frequency range of $10 \mathrm{KHz}$ to $0.01 \mathrm{~Hz}$ at $30{ }^{\circ} \mathrm{C}$ for $30 \mathrm{~min}$ immersion. The measurements were automatically controlled by $Z_{\text {view }}$ software and the impedance diagrams are given as Nyquist plots $\left(Z_{\text {real }}\right.$ versus $\mathrm{Z}_{\text {imaginary }}$ ). From the Nyquist plots, the charge transfer resistance $\left(\mathrm{R}_{\mathrm{ct}}\right)$ was calculated. The inhibition efficiency of the inhibitor has been found out from the $\mathrm{R}_{\mathrm{ct}}$ values according to the eqn. 5.

$$
\text { Inhibition efficiency }(\%)=\frac{\mathrm{R}_{\mathrm{ct}}-\mathrm{R}_{\mathrm{ct}}^{\mathrm{o}}}{\mathrm{R}_{\mathrm{ct}}} \times 100
$$

where, $\mathrm{R}_{\mathrm{ct}}$ and $\mathrm{R}_{\mathrm{ct}}^{\circ}$ are the charge transfer resistance with and without inhibitor respectively. Double layer capacitance $\left(\mathrm{C}_{\mathrm{dl}}\right)$ was obtained from the impedance measurements by using eqn. 6 .

$$
\mathrm{C}_{\mathrm{dl}}=1 / 2 \pi \mathrm{f}_{\max } \mathrm{R}_{\mathrm{ct}}
$$

where, $f_{\max }$ is the frequency value at which the imaginary component of the impedance is maximal.

\section{RESULTS AND DISCUSSION}

\section{Gravimetric method}

Effect of GEG concentration: The inhibition performance of mild steel in $1 \mathrm{~N} \mathrm{HCl}$ in the presence and absence of different concentrations of GEG has been studied at 303-323 K for $1 \mathrm{~h}$ using gravimetric method. The weight loss data obtained from this method are used to determine the corrosion rate, inhibition efficiency and surface coverage (Table-1). Analysis of data (Table-1) revealed that the corrosion rate of mild steel in acidic medium decreases with increasing the concentration GEG at room temperature. This may be due to good inhibiting ability of GEG on mild steel surface which results lesser corrosion rate. Increasing inhibition efficiency of GEG on mild steel can be explained as follows. In acid medium the biopolymer of GEG undergoes acid hydrolysis and produce carbohydrate monomers, proteins and other organic constituents such as

TABLE-1

CORROSION PARAMETERS FOR CORROSION INHIBITION OF GEG ON MILD STEEL IN 1 N HCl

\begin{tabular}{cccc|ccc|ccc}
\hline \multirow{2}{*}{$\mathrm{C}(\mathrm{ppm})$} & \multicolumn{3}{c}{$303 \mathrm{~K}$} & \multicolumn{3}{c|}{$313 \mathrm{~K}$} & \multicolumn{2}{c}{$323 \mathrm{~K}$} \\
\cline { 2 - 9 } & IE $(\%)$ & CR (mmpy) & $\theta$ & IE $(\%)$ & CR (mmpy) & $\theta$ & IE $(\%)$ & CR (mmpy) & $\theta$ \\
\hline Blank & - & 0.08166 & - & - & 0.16029 & - & - & 0.24384 \\
10 & 13.89 & 0.07032 & 0.1389 & 12.03 & 0.14101 & 0.1203 & 10.70 & 0.21775 & 0.1070 \\
50 & 25.46 & 0.06086 & 0.2546 & 26.42 & 0.11795 & 0.2642 & 18.91 & 0.19772 & 0.1891 \\
100 & 31.94 & 0.05557 & 0.3194 & 35.38 & 0.10358 & 0.3538 & 25.27 & 0.18222 & 0.2527 \\
150 & 36.11 & 0.05217 & 0.3611 & 36.79 & 0.10132 & 0.3679 & 25.89 & 0.18070 & 0.2589 \\
200 & 42.13 & 0.04726 & 0.4213 & 38.68 & 0.09829 & 0.3868 & 29.92 & 0.17088 & 0.2992 \\
\hline
\end{tabular}


poly phenols. These hydrolyzed products have more number of surface active units such as $-\mathrm{NH}_{2},-\mathrm{OH}$ and $-\mathrm{COOH}$ groups which are electrochemically active and can interact with positive charge of mild steel surface through their non bonding electrons. Due to good binding capacity as well as polymeric nature of GEG the more number of hydrolyzed monomers are electrostatically interacted with already adsorbed monomers through intermolecular hydrogen bonding and a thick layer on the mild steel surface. This prevents the contact of aggressive medium with mild steel surface. At higher concentration the rate of hydrolysis of GEG decreases and the polymeric material is expected to adsorb as such on the mild steel surface and this protects more efficiently. The decreased metal protection efficiency of GEG with increasing temperature may lead to desorption of adsorbed monomers due to cleavage of hydrogen bonding, suggesting the physical adsorption.

Synergistic influence of iodide ion on GEG: The synergistic influence caused by iodide ion on the corrosion inhibition performance of GEG on mild steel dissolution in $1 \mathrm{~N} \mathrm{HCl}$ was investigated using weight loss method for $1 \mathrm{~h}$ immersion period at 303-323 K. The corrosion rate, surface coverage, inhibition efficiency and synergistic parameter were calculated using weight loss data and are summarized in Table-2. Analysis of data (Table-2) clearly revealed that the rate of reduction of mild steel dissolution in acidic medium significantly decreases by the addition of $4 \mathrm{mM}$ concentration of KI to $50 \mathrm{ppm}$ of GEG. The inhibition potential of the mixture is maximum in comparison with individual partners and their mechanism of synergism can be explained as follows. In $\mathrm{HCl}$ medium the mild steel surface gets polarized and behaves as positively charged. Iodide ion present in mixture strongly interact with mild steel surface through electrostatic interaction on $\mathrm{Fe}^{2+}$ ion of mild steel due to its large ionic radius, high hydrophobicity and low electronegativity [3-8]. After stabilization of positive charge $\left(\mathrm{Fe}^{2+}\right)$, the iodide ions are strongly adsorbed on mild steel surface, which results with development of excess negative charge on mild steel surface. Simultaneously presence of GEG in aggressive medium undergoes acid hydrolysis and produces monomers of carbohydrates and proteins units. Now adsorbed iodide ions act as intermediate bridge between positively charged mild steel surface and labile electrons of hetero atoms present in hydrolyzed monomers of GEG such as carbohydrates and proteins units [3-8]. Stabilization of the adsorbed iodide ions by means of interaction with the GEG leads to grater surface coverage arising from the ion-pair interactions between the organic constituents of GEG and iodide ion. This behaviour can be attributed to increasing the surface coverage ability of GEG on mild steel and form good protective film/layer/blanket on the steel surface. Due to polymeric and viscous nature of GEG the more number of hydrolyzed carbohydrate and protein monomers are able to interact with already adsorbed monomers which results excellent inhibition efficiency. Further to confirm the existence of synergism between GEG and iodide ions towards the adsorption on mild steel, a synergism parameter $\left(\mathrm{S}_{\theta}\right)$ has been calculated using the relationship (eqn. 7) given by Aramaki et al. [9].

$$
S_{\theta}=\frac{1-I_{(1+2)}}{1-I_{(1+2)}^{\prime}}
$$

TABLE-2

CORROSION PARAMETERS FOR SYNERGISTIC

INFLUENCE OF IODIDE ION ON INHIBITION OF GEG ON MILD STEEL IN $1 \mathrm{~N} \mathrm{HCl}$

\begin{tabular}{llccc}
\hline \multirow{2}{*}{$(\mathrm{K})$} & \multicolumn{1}{c}{$\mathrm{C}(\mathrm{ppm})$} & $\mathrm{IE}(\%)$ & $\begin{array}{c}\mathrm{CR} \\
(\mathrm{mmpy})\end{array}$ & $\mathrm{S}_{\theta}$ \\
\hline \multirow{2}{*}{303} & $4 \mathrm{mM} \mathrm{KI}$ & 24.54 & 0.06162 & \multirow{2}{*}{0.91} \\
& $50 \mathrm{ppm} \mathrm{GEG} \mathrm{+} \mathrm{4} \mathrm{mM} \mathrm{KI}$ & 54.63 & 0.03705 & \\
\hline \multirow{2}{*}{313} & 4 mM KI & 10.61 & 0.14328 & \multirow{2}{*}{0.93} \\
& $50 \mathrm{ppm} \mathrm{GEG} \mathrm{+} \mathrm{4} \mathrm{mM} \mathrm{KI}$ & 39.86 & 0.09640 & \\
\hline \multirow{2}{*}{323} & $4 \mathrm{mM} \mathrm{KI}$ & 7.44 & 0.22569 & \multirow{2}{*}{0.96} \\
& $50 \mathrm{ppm} \mathrm{GEG} \mathrm{+4} \mathrm{mM} \mathrm{KI}$ & 27.44 & 0.17692 & \\
\hline
\end{tabular}

where, $I_{(1+2)}=I_{1}+I_{2}, I_{1}=$ inhibition efficiency of GEG, $I_{2}=$ inhibition efficiency of iodide ion and $\mathrm{I}_{(1+2)}$ is measured inhibition efficiency for GEG in combination with iodide ion. The values of $S_{\theta}$ for the combination of GEG and iodide ion, which are close to unity, show a synergism between two reacting species towards the corrosion inhibition of mild steel in $1 \mathrm{~N} \mathrm{HCl}$ (Table-2). The effect of temperature on synergism was also studied for optimum concentration at 313 and $323 \mathrm{~K}$ and their data are listed in Table-2. As the temperature increases inhibition efficiency of GEG-iodide mixture decreases but the rate of decrease with raise in temperature is very less compared to GEG alone. From this analysis it is clear that the synergistic effect is more pronounced at elevated temperature than at lower temperature.

Thermodynamic and kinetic analysis: In general, the rate of dissolution of mild steel in acidic medium increases with increasing the temperature and it is related to Arrhenius equation. Thermodynamic parameters of the corrosion reaction namely activation energy $\left(E_{a}\right)$, entropy of activation $\left(\Delta S^{*}\right)$ and enthalpy of activation $\left(\Delta \mathrm{H}^{*}\right)$ were calculated using Arrhenius eqn. 8 and its alternative formulation called transition state eqn. 9 .

$$
\mathrm{C}_{\mathrm{R}}=\mathrm{A} \exp ^{(-\mathrm{E} / \mathrm{RT})}
$$

where $C_{R}, A, E_{a}, R$ and $T$ is the corrosion rate, Arrhenius preexponential factor, activation energy, universal gas constant and absolute temperature respectively. Arrhenius plots (log $\mathrm{C}_{\mathrm{R}} v s .1000 / \mathrm{T} \mathrm{K}^{-1}$ ) for mild steel in the absence and presence of GEG and optimum concentration of GEG $+\mathrm{I}^{-}$are shown in Fig. 1. The values of $E_{a}$ of corrosion process were calculated from the slopes $\left(-E_{a} / 2.303 R\right)$ of the straight line obtained from Arrhenius plots. Analysis of data (Table-3) clearly revealed that $\mathrm{E}_{\mathrm{a}}$ value for GEG and optimum concentration of GEG $+\mathrm{I}^{-}$is much higher than uninhibited solutions [10]. This higher $E_{a}$ values for the studied inhibitor is due to the increase in the energy barrier for the corrosion reaction and suggest the physical adsorption [11]. In order to calculate the activation parameters like $\Delta \mathrm{H}^{*}, \Delta \mathrm{S}^{*}$ for the corrosion process, transition state equation was used.

$$
\mathrm{K}=\mathrm{RT} / \mathrm{Nh} \exp ^{(\Delta S * \mathbb{R})} \exp ^{\left(-\Delta H^{*} / \mathrm{RT}\right)}
$$

where $\mathrm{N}, \mathrm{h}, \Delta \mathrm{S}^{*}$ and $\Delta \mathrm{H}^{*}$ is the Avogadro's number, planck's constant, entropy of activation and enthalpy of activation respectively. The plot of $\log \left(\mathrm{C}_{\mathrm{R}} / \mathrm{T}\right) v s .1000 / \mathrm{T} \mathrm{K}^{-1}$ gave straight line (Fig. 2) with slope $\left(-\Delta \mathrm{H}^{*} / 2.303 \mathrm{R}\right)$ and intercept (log R/Nh + $\Delta \mathrm{S}^{*} / 2.303 \mathrm{R}$ ), from which $\Delta \mathrm{H}^{*}$ and $\Delta \mathrm{S}^{*}$ are calculated (Table3 ). The positive value of $\Delta \mathrm{H}^{*}$ indicates the dissolution of mild steel is endothermic nature and this process is very difficult 


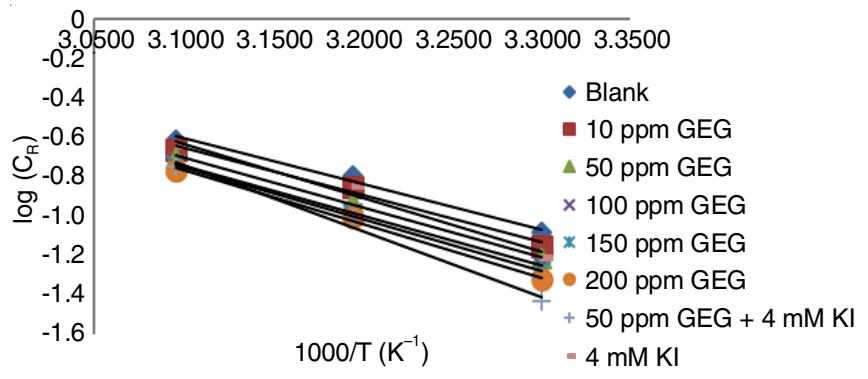

Fig. 1. Arrhenius plots for GEG, KI and their mixture on mild steel in $1 \mathrm{~N}$ $\mathrm{HCl}$

\begin{tabular}{cccc} 
TABLE-3 \\
ACTIVATION PARAMETERS FOR GEG, KI AND \\
THEIR MIXTURE ON MILD STEEL IN 1 N HCl \\
\hline $\mathrm{C}(\mathrm{ppm})$ & $\begin{array}{c}\mathrm{E}_{\mathrm{a}}^{*} \\
\left(\mathrm{~kJ} \mathrm{~mol}^{-1}\right)\end{array}$ & $\begin{array}{c}\Delta \mathrm{H}^{*} \\
\left(\mathrm{~kJ} \mathrm{~mol}^{-1}\right)\end{array}$ & $\begin{array}{c}\Delta \mathrm{S}^{*} \\
\left(\mathrm{~J} \mathrm{~mol}^{-1}\right)\end{array}$ \\
\hline Blank & 44.61 & 42.01 & -126.98 \\
10 & 46.09 & 43.49 & -123.32 \\
50 & 47.99 & 45.39 & -118.42 \\
100 & 48.33 & 45.73 & -118.17 \\
150 & 50.57 & 47.97 & -111.26 \\
200 & 52.36 & 49.76 & -106.05 \\
$50 \mathrm{ppm}$ GEG + 4 mM KI & 63.75 & 61.15 & -70.27 \\
$4 \mathrm{mM} \mathrm{KI}$ & 52.98 & 50.37 & -101.54 \\
\hline
\end{tabular}

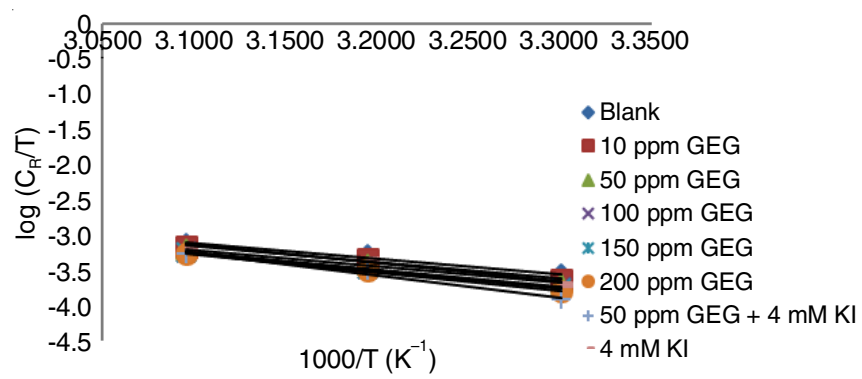

Fig. 2. Transition plots for GEG, KI and their mixture on mild steel in $1 \mathrm{~N}$ $\mathrm{HCl}$

[12]. The higher value of $\Delta \mathrm{H}^{*}$ for GEG and GEG + $\mathrm{I}^{-}$compared to blank suggests that there is an increasing energy barrier for the corrosion process and it supports the physical adsorption process [13]. The higher the values of $\Delta S^{*}$ for the studied inhibitor compared to blank suggests that disorderness increased on going from reactant to activated complex [14].

Adsorption isotherm: It is presumed that the corrosion inhibitor functions by adsorption on metal surface and formation of thin protective film or layer that blankets the metal surface from the aggressive medium. This behaviour based on chemical constituents and conformation of inhibitor, nature of the metal surface and temperature. Nature of interaction between the film formed and the metal surface may be explained with the help of adsorption isotherms. The mechanism by which adsorption of inhibitors on metal surface take place may be physical or chemical in nature. In physical mode of adsorption the electrostatic interaction exists between metal surface and inhibitor whereas chemical adsorption involves the interaction of uncharged electron pair of the inhibitor with the metal or interaction of $\pi$ electrons with the metal [15]. Therefore to study the adsorption behaviour of inhibitor on metal surface in aggressive medium the surface coverage value of inhibitor is most useful parameters. The value of surface coverage obtained from weight loss measurements for various concentrations of GEG have been applied to different adsorption isotherm equations and the best fit was obtained for Langmuir's isotherm. The Langmuir isotherm is given by eqn. 10.

$$
\mathrm{C} / \theta=1 / \mathrm{K}_{\mathrm{ads}}+\mathrm{C}
$$

where, $C, K_{a d s}$ and $\theta$ are concentration of GEG, equilibrium constant adsorption process and degree of surface coverage respectively. The plots of $(\mathrm{C} / \theta) v s$. C for GEG gave straight lines with almost unit slope (figure not shown). The values of $\mathrm{K}_{\mathrm{ads}}$ were derived from intercept of the Langmuir's isotherm plot and it can be related to $\Delta \mathrm{G}_{\text {ads }}^{\circ}$ by the expression (eqn. 11).

$$
\left(\Delta \mathrm{G}^{\circ}{ }_{\text {ads }}\right)=2.303 \times \mathrm{RT} \log (55.5 \times \mathrm{K})
$$

where, $\Delta \mathrm{G}_{\text {ads, }}^{\circ} \mathrm{R}, \mathrm{T}$ is standard free energy of adsorption process, universal gas constant, absolute temperature respectively and the value 55.5 indicates concentration of water in solutions expressed in $\mathrm{mol} / \mathrm{L}$. The values of $\Delta \mathrm{G}^{\circ}$ ads were calculated from the above expression and are listed in Table- 4 . The negative values of $\Delta \mathrm{G}^{\circ}$ ads indicate spontaneous adsorption of inhibitor molecules on mild steel surface and also the strong interaction between inhibitor molecules and the metal surface. Usually the values around $-20 \mathrm{~kJ} \mathrm{~mol}^{-1}$ or lower are consistent with physisorption while those higher than $-40 \mathrm{~kJ} \mathrm{~mol}^{-1}$ involve chemisorptions [16]. The calculated $\Delta \mathrm{G}^{\circ}$ ads are in the range between 16.56 and $17.25 \mathrm{~kJ} \mathrm{~mol}^{-1}$ confirming physical adsorption nature.

\begin{tabular}{ccccc}
\multicolumn{5}{c}{ TABLE-4 } \\
ADSORPTION PARAMETERS FOR CORROSION \\
\hline \multicolumn{5}{c}{ INHIBITION OF GEG ON MILD STEEL IN 1 N HCl } \\
\hline $\mathrm{T}(\mathrm{K})$ & Intercept & $\mathrm{K}\left(\mathrm{mol}^{-1}\right)$ & $\begin{array}{c}-\Delta \mathrm{G}_{\text {ads }}^{\circ} \\
\left(\mathrm{kJ} \mathrm{mol}^{-1}\right)\end{array}$ & $\mathrm{R}^{2}$ \\
\hline 303 & 0.0777 & 12.86 & 16.56 & 0.9761 \\
313 & 0.0653 & 15.30 & 17.55 & 0.9981 \\
323 & 0.0901 & 11.10 & 17.25 & 0.9852 \\
\hline
\end{tabular}

\section{Electrochemical measurements}

Tafel's polarization studies: Kinetics of anodic and cathodic reactions occurring on mild steel in $1 \mathrm{~N} \mathrm{HCl}$ in the absence and presence of GEG and GEG together with iodide ion was investigated using Tafel's polarization method and their corresponding Tafel's plots are shown in Fig. 3. Polarization parameters such as $i_{\text {corr }}, E_{\text {corr }}$ and Tafel's slope $\left(b_{a}\right.$ and $\left.b_{c}\right)$ were derived from the Tafel's plot and summarized in Table-5. It is evident from the Tafel's plot (Fig. 3) that the nature of plot remained the same in the absence and presence of tested inhibitors system. This clearly reveals that the presence of GEG and GEG $+\mathrm{I}^{-}$reduces the dissolution rate of mild steel in $1 \mathrm{~N}$ $\mathrm{HCl}$ but does not affect the other aspects of the electrochemical behaviour responsible for corrosion. Data presented in Table5 clearly revealed that the value of $i_{\text {corr }}$ noticeably decreases in the presence of GEG and drastically decreased in the case of GEG $+\mathrm{I}^{-}$but there is no remarkable change in $\mathrm{E}_{\text {corr }}$ and Tafel slope values. This suggest that the rate of dissolution of mild steel was retarded due to the formation of a protective layer of inhibiting monomers of GEG on mild steel surface but in case 


\begin{tabular}{|c|c|c|c|c|c|}
\hline \multicolumn{6}{|c|}{$\begin{array}{c}\text { TABLE-5 } \\
\text { POLARIZATION PARAMETERS FOR OPTIMUM CONCENTRATION OF GEG, KI AND THEIR MIXTURE ON MILD STEEL IN } 1 \text { N HCl }\end{array}$} \\
\hline Inhibitor & $-\mathrm{E}_{\text {corr }}(\mathrm{mV} / \mathrm{SCE})$ & $\mathrm{i}_{\text {corr }}\left(\mathrm{mA} / \mathrm{cm}^{2}\right)$ & $\mathrm{b}_{\mathrm{a}}(\mathrm{mV} / \mathrm{dec})$ & $\mathrm{b}_{\mathrm{c}}(\mathrm{mV} / \mathrm{dec})$ & $\operatorname{IE}(\%)$ \\
\hline Blank & -0.477 & 0.00161 & 0.147 & 0.078 & - \\
\hline 50 ppm GEG & -0.476 & 0.00047 & 0.117 & 0.062 & 70.80 \\
\hline 50 ppm GEG + 4 mM KI & -0.489 & $5.49 \mathrm{E}-05$ & 0.106 & 0.085 & 96.59 \\
\hline
\end{tabular}

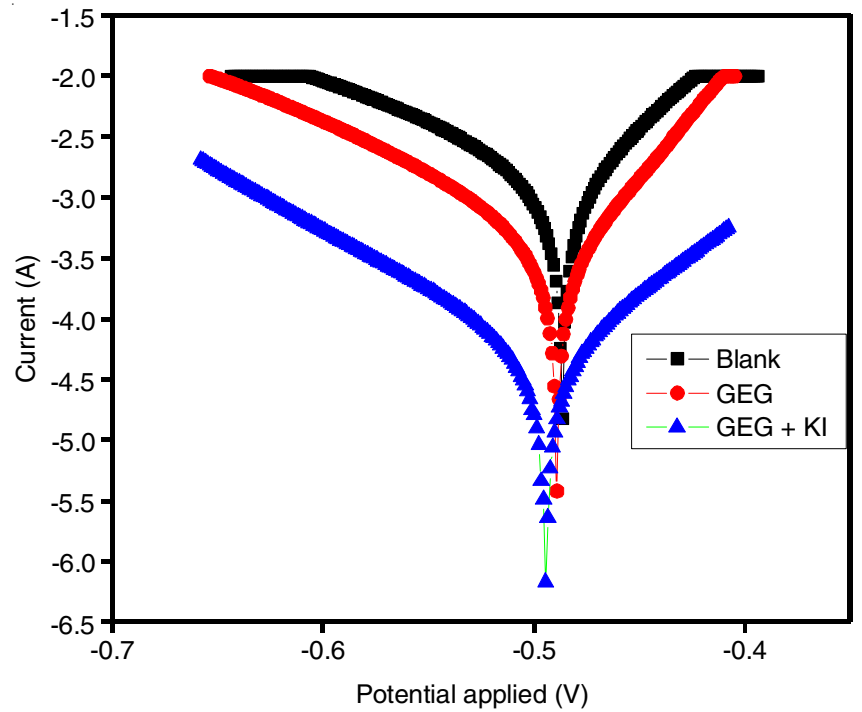

Fig. 3. Tafel's plots for optimum concentration of GEG, KI and their mixture on mild steel in $1 \mathrm{~N} \mathrm{HCl}$

of GEG $+\mathrm{I}^{-}$system strong layer is formed and it is mainly due to synergistic influence of iodide ion on GEG. This formed protective layer on mild steel creates a barrier between mild steel and aggressive medium, which causes a decrease in $i_{\text {corr }}$ value of mild steel and hence better corrosion inhibition efficiency. It is also clear from Fig. 3 that as the investigated inhibitor system is added to the $1 \mathrm{~N} \mathrm{HCl}$ medium it retards both the anodic dissolution of mild steel and cathodic hydrogen evolution reaction. Generally the change observed in the polarization curve in the presence of inhibitors is used as criteria to categorize inhibitors as cathodic, anodic or mixed type [17]. Therefore the studied inhibitors are functioning by mixed type inhibition mechanism [18]. This means that the GEG and mixture of GEG and KI system have significant effects on retarding both the anodic dissolution of mild steel and inhibiting the cathodic hydrogen evolution.

Impedance studies: It is a versatile tool for predicting the adsorption tendency of inhibitor on metal in the form of protective film or layer during their inhibition in aggressive medium. Therefore the nature of inhibition process of GEG and synergistic influence of iodide ion on corrosion inhibition of GEG towards mild steel dissolution in $1 \mathrm{~N} \mathrm{HCl}$ was confirmed using impedance parameters $\left(\mathrm{R}_{\mathrm{ct}}\right.$ and $\left.\mathrm{C}_{\mathrm{dl}}\right)$. Results obtained from this method for mild steel in $1 \mathrm{~N} \mathrm{HCl}$ in the absence and presence of optimum concentration of GEG and $\mathrm{GEG}+\mathrm{I}^{-}$were presented in the form of Nyquist plots (Fig. 4) and their impedance values such $\mathrm{R}_{\mathrm{ct}}$ and $\mathrm{C}_{\mathrm{dl}}$ derived from this plots are given in Table-6. It was observed that a diameter of semicircle $\left(\mathrm{R}_{\mathrm{ct}}=31.30\right)$ noticeably increased in the case of GEG indicating that the higher surface coverage of GEG on mild steel surface indicates protective film formation leading to better inhibition. But in the case of GEG $+\mathrm{I}^{-}$system the

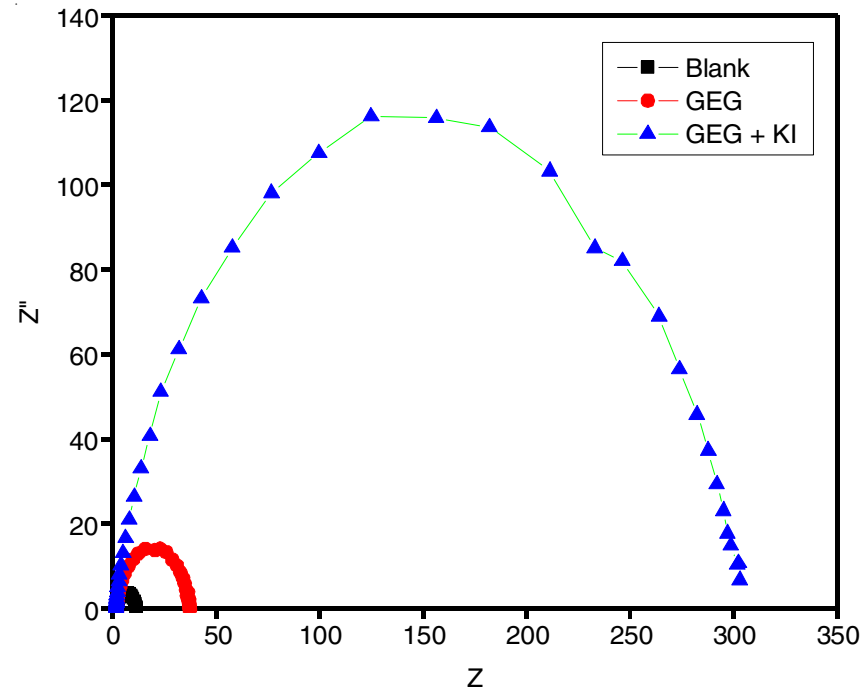

Fig. 4. Nyquist plots for optimum concentration of GEG, KI and their mixture on mild steel in $1 \mathrm{~N} \mathrm{HCl}$

\begin{tabular}{cccc} 
TABLE-6 \\
IMPEDANCE PARAMETERS FOR OPTIMUM \\
CONCENTRATION OF GEG, KI AND THEIR \\
MIXTURE ON MILD STEEL IN 1 N HCl \\
\hline Inhibitor & $\mathrm{R}_{\mathrm{ct}}\left(\Omega \mathrm{cm}^{2}\right)$ & $\mathrm{C}_{\mathrm{dl}}\left(\mu \mathrm{F} \mathrm{cm}{ }^{-2}\right)$ & $\mathrm{IE}(\%)$ \\
\hline Blank & 07.05 & 61.3 & - \\
50 ppm GEG & 31.30 & 77.7 & 77.47 \\
$50 \mathrm{ppm}$ GEG + 4 mM KI & 260.26 & 51.2 & 97.29 \\
\hline
\end{tabular}

diameter of the semicircle plot are increased significantly $\left(\mathrm{R}_{\mathrm{ct}}\right.$ $=260.26$ ). Presence of iodide ions in GEG $+\mathrm{I}^{-}$system synergistically increase the corrosion inhibition of GEG on mild steel in $1 \mathrm{~N} \mathrm{HCl}$ which results in greater the surface coverage of GEG and creates more shielding on the mild steel surface. An increase the resistance towards the electron transfer for dissolution of mild steel increases the value of $R_{\mathrm{ct}}$ followed by simultaneous decreases of electrical double layer $\left(\mathrm{C}_{\mathrm{dl}}\right)$. This may be due to displacement or removal of adsorbed water molecules from the mild steel surface followed by simultaneous adsorption of inhibitors on the surface which results excellent corrosion protection efficiency.

\section{Conclusion}

- Gum exudates of Eucalyptus globles (GEG) act as good green corrosion inhibitor for dissolution control of mild steel in $1 \mathrm{~N} \mathrm{HCl}$ at room temperature.

- A mixture of GEG and iodide ions system behaves as excellent green corrosion inhibitor and reduces the rate of dissolution of mild steel in $1 \mathrm{~N} \mathrm{HCl}$. This may be due synergistic effect existing between GEG and iodide ion on mild steel which results in the formation of thermally stable protective film on mild steel and controls or protects the dissolution of mild steel. 
- Thermodynamic and kinetic parameters clearly reveals that adsorption of GEG and their iodide mixture on mild steel in $1 \mathrm{~N} \mathrm{HCl}$ obeys physisorption process which is further confirmed in Langmuir's isotherm.

- Tafel's plots show the mixed nature of the studied inhibitors system.

- The increase in $\mathrm{R}_{\mathrm{ct}}$ values decrease in $\mathrm{C}_{\mathrm{dl}}$ values shows the corrosion control nature of GEG and its mixture with iodide ions.

\section{CONFLICT OF INTEREST}

The authors declare that there is no conflict of interests regarding the publication of this article.

\section{REFERENCES}

1. S.A. Umoren and U.M. Eduok, Carbohydr. Polym., 140, 314 (2016); https://doi.org/10.1016/j.carbpol.2015.12.038.

2. A. Peter, I.B. Obot and S.K. Sharma, Int. J. Indus. Chem., 6, 153 (2015); https://doi.org/10.1007/s40090-015-0040-1.

3. S.A. Umoren, Port. Electrochim. Acta, 27, 565 (2009); https://doi.org/10.4152/pea.20090556.

4. S.A. Umoren and E.E. Ebenso, Pigm. Res. Technol., 37, 173 (2008); https://doi.org/10.1108/03699420810871020.

5. P. Ameh, A.O. Odiongenyi and N.O. Eddy, Port. Electrochim. Acta, 30, 235 (2012);

https://doi.org/10.4152/pea.201204235.
6. S.A. Umoren, I.B. Obot and E.E. Ebenso, E-J. Chem., 5, 355 (2008); https://doi.org/10.1155/2008/138407.

7. S.A. Umoren and U.F. Ekanem, Chem. Eng. Commun., 197, 1339 (2010); https://doi.org/10.1080/00986441003626086.

8. S.A. Umoren, I.B. Obot, E.E. Ebenso and N.O. Obi-Egbedi, Int. J. Electrochem. Sci., 3, 1029 (2008).

9. K. Aramaki, M. Hagiwara and H. Nishihara, Corros. Sci., 27, 487 (1987); https://doi.org/10.1016/0010-938X(87)90092-8.

10. S.A. Umoren, M.M. Solomon, I.I. Udosoro and A.P. Udoh, Cellulose, 17, 635 (2010); https://doi.org/10.1007/s10570-010-9409-7.

11. M.M. Solomon, S.A. Umoren, I.I. Udosoro and A.P. Udoh, Corros. Sci., 52, 1317 (2010); https://doi.org/10.1016/j.corsci.2009.11.041.

12. G.N. Mu, X. Li and F. Li, Mater. Chem. Phys., 86, 59 (2004); https://doi.org/10.1016/j.matchemphys.2004.01.041.

13. S.K. Shukla and E.E. Ebenso, Int. J. Electrochem. Sci., 6, 3277 (2011).

14. I. Ahamad, R. Prasad and M.A. Quraishi, Corros. Sci., 52, 933 (2010); https://doi.org/10.1016/j.corsci.2009.11.016.

15. E. Ituen, O. Akaranta and A. James, Chem. Sci. Int. J., 18, 1 (2017); https://doi.org/10.9734/CSJI/2017/28976.

16. S.A. Umoren, I.B. Obot, E.E. Ebenso, P.C. Okafor, O. Ogbobe and E.E. Oguzie, Anti-Corros. Methods Mater, 53, 277 (2006); https://doi.org/10.1108/00035590610692554.

17. N.O. Eddy and E.E. Ebenso, Afr. J. Pure. Appl. Chem., 2, 46 (2008)

18. A. Bouyanzer and B. Hammouti, Pig. Res. Tech., 33, 287 (2004); https://doi.org/10.1108/03699420410560489. 